\title{
Unemployment and Job Creation
}




\section{ECONOMICS TODAY}

Edited by Andrew Leake

The Economics Today series surveys contemporary headline topics in applied economics. Each book in the series is written by an expert in the field in a style that is fluently readable. It serves the student of introductory economic principles while also making the subject accessible to a more general reader. The series embraces the problemsolving skills of the new generation of students and stresses the importance of real-world issues and the significance of economic ideas.

\section{Published}

Andrew Leake: The Economic Question

Jean-Louis Barsoux and Peter Lawrence: The Challenge of

British Management

Andy Beharrell: Unemployment and Job Creation

Frank Burchill: Labour Relations

S.F Goodman: The European Community

Jenny Wales: Investigating Social Issues

\section{Forthcoming}

Kenneth Durham: The New City

Margaret Wilkinson: Taxation

\section{Series Standing Order}

If you would like to receive future titles in this series as they are published, you can make use of our standing order facility. To place a standing order please contact your bookseller or, in case of difficulty, write to us at the address below with your name and address and the name of the series. Please state with which title you wish to begin your standing order. (If you live outside the United Kingdom we may not have the rights for your area, in which case we will forward your order to the publisher concerned.)

Standing Order Service, Macmillan Distribution Ltd, Houndmills, Basingstoke, Hampshire, RG21 2XS, England. 


\section{UNEMPLOYMENT}

AND

JOB CREATION

Andy Beharrell

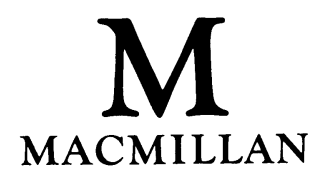


All rights reserved. No reproduction, copy or transmission of this publication may be made without written permission.

No paragraph of this publication may be reproduced, copied or transmitted save with written permission or in accordance with the provisions of the Copyright, Designs and Patents Act 1988 , or under the terms of any licence permitting limited copying issued by the Copyright Licensing Agency, 90 Tottenham Court Road, London W1P 9HE.

Any person who does any unauthorised act in relation to this publication may be liable to criminal prosecution and civil claims for damages.

First published 1992

Published by

MACMILLAN EDUCATION LTD

Houndmills, Basingstoke, Hampshire RG21 2XS

and London

Companies and representatives

throughout the world

ISBN 978-0-333-56300-7 ISBN 978-1-349-21826-4 (eBook)

DOI 10.1007/978-1-349-21826-4

A catalogue record for this book

is available from the British Library.

Typeset by

Ponting-Green Publishing Services, London 
For Anne and Alex 
'Work is of two kinds; first, altering the position of matter at or near the earth's surface relatively to other matter; second, telling other people to do so. The first is unpleasant and illpaid; the second is pleasant and highly paid.' (Bertrand Russell, 'The conquest of happiness')

'In a hierarchy every employee tends to rise to his level of incompetence ... Work is accomplished by those who have not yet reached their level of incompetence.' (Laurence J. Peter, 1969) 


\section{Contents}

List of Tables and Figures $x$

1 Where Are the Jobs? 1

Who Is Working? 1

The Market for Labour 5

How Have Jobs Changed? 8

Is Work a Full-time Occupation? 9

Where Are We Working? 11

Who Are We Working For? 14

Going It Alone 16

What Are We Doing? 18

What Type of Industries? 20

2 Who Are the Unemployed? 22

Types of Unemployment 23

How Many Are Unemployed? 25

So how many are really unemployed? 30

Are the official figures an underestimate? 30

Could the unemployment figures be an overstatement? 31

A Pool of Unemployed 32

Who Is Unemployed? 33

How Long Have They Been Unemployed? 36 
viii Contents

3 The Ups and Downs of Unemployment 39

The Keynesian View - Are We Spending Enough? 40

What Does It All Add Up To? 42

Can Keynesian Theory Help Explain the Recent

Past? 46

Can We Compete? 51

It Must Be the Machine 53

Too Many People? 54

4 The Right People for the Right Jobs

Classical Theory - a Perfect Market? 57

So Where Do the Faults Lie? 59

Are We Paying Ourselves Too Much? 61

Is It Too Expensive to Employ People? 66

Why Work? 70

It Must Be the Fault of the Unions! 74

Mismatches 75

5 Creating Jobs - Spend More? 80

'Fine-tuning' 81

What Do the Monetarists Think of This? 86

1980s Macro-economic Policy 88

Reflation - Fiscal Style 89

Financing the Expansion 93

What About Wages? 94

Incomes policy 94

A wages tax? 97

6 Creating Jobs - What About the Supply Side? 100

Incentives 101

Trade Union Reforms 105

Making Labour More Mobile 108

Making Labour Cheaper 114

Workfare 115 
7 The UK - The Best of the Rest? 117

France 119

West Germany 121

Sweden 125

So What Can We Learn? 129

8 Is Unemployment Inevitable? 132

The Phillips Curve 132

Friedman's Formulation of the Phillips Curve 135

So What Is Unemployment 'Naturally'? 140

Does All This Explain the 1970s and 1980s? 143

So Is Unemployment Inevitable? 144

9

Are New Habits Here to Stay? 149

What Are the New Habits? 149

What About the Government - a Help or a

Hindrance? 151

Job Subsidies 154

Share and Share Alike? 155

The Demographic Time-bomb 157

What Will Happen When the Bomb Goes Off? 160

Can the Bomb Be Defused? 162

Will The New Habits Stay? 163

Index 167 


\section{List of Tables and Figures}

\section{Tables}

1.1 Percentage of Workforce on Temporary Work, 1984-9 9

1.2 Number of People with a Second Job 11

2.1 Alternative definitions of unemployment 29

2.2 Unemployment by Ethnic Origin, Spring 198936

4.1 Trade Union Membership, 1976-89 75

5.1 Incomes Policies - Do They Work? 96

8.1 Actual and 'Natural' Rates of Unemployment, 1967-83 141

9.1 Government Schemes, 1989152

\section{Figures}

1.1 Male and Female Employment, 1960-89 3

1.2 Economic Activity Rates - Changes with Age and Marital Status 4

1.3 Backward-bending Supply Curve for Labour 6

1.4 Labour Market Equilibrium 7

1.5 Part-time Working 10

1.6 Unemployment by Region 13

1.7 Self-employment as a Percentage of Total workforce in employment 17

1.8 Changes in Employment in Manufacturing, Construction and Services 19

1.9 Employment Changes in Industry 21 
2.1 Comparison of Two Different Measures of Unemployment, 198927

2.2 Unemployment, Annual Averages 28

2.3 Unemployment by Age and Sex, $1989 \quad 34$

2.4 Unemployment by Qualification 35

2.5 Unemployment by Length 37

2.6 Longer Unemployment as You Get Older? Percentage of Total Unemployed, April 198838

3.1 The Consumption Function 41

3.2 Equilibrium 43

3.3 The Deflationary Gap 44

3.4 Trade Cycle - Boom and Bust 46

3.5 Changes in Spending 47

3.6 How Much Do We Save? 48

3.7 A Shortage of Capital? 50

3.8 Too Many People? 55

4.1 Voluntary Unemployment 59

4.2 Effect of Trade Unions on the Labour Market 61

4.3 Increased Productivity 64

4.4 Real Earnings Growth, 1980-9 65

4.5 Effect of Higher Non-wage Costs 67

4.6 Minimum Wages - Lower Employment 69

4.7 Replacement Ratios 72

4.8 Trade Unions Resisting Change 76

4.9 A Lack of Skilled Workers? 79

5.1 A Reflationary Package 84

5.2 Effect on the Labour Market of Reflation 95

6.1 A More Flexible Market 101

6.2 What Are 16-18-year-olds Doing? 110

6.3 House Price Differentials, 1990113

7.1 UK - The Best of the Rest? 118

7.2 Spending on Labour Market Measures, Selected Countries 130

8.1 The Original Phillips Curve 133

8.2 The Broken-down Phillips Curve? 134

8.3 The Natural Rate 136

8.4 Friedman's Version of the Phillips Curve (Expectationsaugmented) 137 


\section{xii List of Tables and Figures}

8.5 Supply-side and Demand-side Policy 146

8.6 Reflating to Get Rid of Unemployment 147

9.1 The Future Labour Force (1990-2001)? 158

9.2 Workforces, 1989, $2001 \quad 159$ 